\title{
Concern About the Association Between Sex and Birth Weight of Babies: A Cross-Sectional Randomized Finding From a Nigerian Hospital
}

\begin{abstract}
Ahmadu BU', Abubakar IH', Halima A ${ }^{3}$, Ruqayya A $^{4}$, Suleiman $\mathbf{G M}^{5}$

${ }^{1}$ Dr. Baba Usman Ahmadu, MBBS, FMCPaed (Consultant Paediatrician) Department of Paediatrics, Federal Medical Centre, Yola, Adamawa State, Nigeria, ${ }^{2}$ Dr. Ibrahim Halima Abubakar, MBBS, MWACP (Senior Registrar) Department of Paediatrics, University of Maiduguri Teaching Hospital, Maiduguri, Nigeria, ${ }^{3}$ Dr. Abdulrahim Halimat, MBBS (Registrar) Department of Paediatrics, University of Maiduguri Teaching Hospital, Maiduguri, Nigeria, ${ }^{4}$ Dr. Abubakar Ruqayyah MBBS (Paediatric Registrar) Department of Paediatrics, University of Maiduguri Teaching Hospital, Maiduguri, Nigeria, ${ }^{5}$ Dr. Gimba Mohammed Suleiman, MBBS (Paediatric Registrar) Department of Paediatrics, University of Maiduguri Teaching Hospital, Maiduguri, Nigeria.
\end{abstract}

\section{Introduction}

"6 How much did he or she weigh?" is often the - first question proud parents are asked after they have announced the sex of their newly delivered baby. Sex chromosomes may have a disproportionate influence on birth weight of babies because both $X$ and $Y$ chromosomes are atypical in gene content and activity, as a result of their unique evolutionary trajectory ${ }^{1}$. Some investigators, however, believed that genetic factors and endocrine mechanisms related to sex could play significant roles in determining birth weight of babies. Magnus et $\mathrm{al}^{2}$, in 1984 estimated that genetic influences account for about $80 \%$ of birth weight outcome in babies, and recently some of the specific genes and chromosomal loci involved have been identified ${ }^{3}$. Hattersley and colleagues ${ }^{4}$ in 1998 observed that mothers who had glucokinase gene defects were hyperglycemic, and the birth weights of their offspring were increased by a mean of 601 grams. Also, if a fetus had inherited a glucokinase mutation, the birth weight was decreased by 533 gram, equivalent to a fall from

\footnotetext{
Address for correspondence

Dr. Baba Usman Ahmadu

Department of Paediatrics, Federal Medical Centre Yola,

Yola bye-pass Adamawa state, Nigeria.

E-mail: ahmadu4u2003@yahoo.com
}

\begin{abstract}
Introduction: Sexual antagonism is seen particularly where maternally and paternally derived alleles battle over fetal growth, which may result in sex differences regarding birth weight of babies. We examined the association between sex and birth weight of babies in the University of Maiduguri Teaching Hospital. Materials and Methods: One hundred babies selected by systematic random sampling had their birth weights determined using bassinet weighing scale. Likelihood ratio chi-square test of association was used to investigate the relationship between sex and birth weight. Results: A total of 100 babies participated in this study. There were $53(53.0 \%)$ males and $47(47.0$ $\%)$ females giving a male to female ratio of 1.1:1. Majority of the babies $82(82.0 \%)$ had normal birth weight $(2500-3900 \mathrm{~g})$. The mean (SD) birth weight for male and female babies were 313 (62), $95 \mathrm{Cl}(296-330 \mathrm{~g})$, and 290 (055), $95 \mathrm{Cl}$ $(275-307 \mathrm{~g})$ respectively. The overall mean (SD) birth weight of the babies was $302(0.59), 95 \mathrm{Cl}$ $(291-314 \mathrm{~g})$. Association between birth weight and sex of the babies was found to be significant $\left(X^{2}=9.317, p=0.025\right)$. Conclusion: Birth weight was significantly associated with sex: males had higher birth weights than females.
\end{abstract}

Key words: Sex, Birth weights, Babies, University of Maiduguri Teaching Hospital, Nigeria.

the 50th to the 25th birth weight percentile ${ }^{4}$. Insight into factors that may be involved in human fetal growth has been studied. In particular, insulin-like growth factor (IGF)-I, IGF-II, IGF receptor type 1, insulin and insulin receptor are all critical for normal fetal growth ${ }^{3}$. Furthermore, low birth weight (LBW) in babies has been linked to IGF-I gene defects in humans ${ }^{3}$.

Graves in 2010 argued that the placenta is the site where maternally and paternally derived alleles

\section{How to cite this article?}

Ahmadu BU, Abubakar IH, Halima A, Ruqayya A, Suleiman GM. Concern About the Association Between Sex and Birth Weight of Babies: A Cross-Sectional Randomized Finding From a Nigerian Hospital. J Nepal Paediatr Soc 2013;33(1):21-24. 
have influence on fetal growth ${ }^{1}$. This sexual antagonism is seen particularly in large numbers of genes that show imprinted expression on the placenta more than any other tissue in humans ${ }^{1}$. This may have evolved because of the competing interests of the male parent, a larger offspring, and the female parent surviving to bear offspring from other partners ${ }^{1}$. Many genes on the male-specific region of $Y$ chromosomes are dedicated to sex and reproduction, making the $Y$ chromosome quite unique in its functional coherence ${ }^{5,6}$. This may possibly lead to higher birth weight in males compared to female babies. In this review, the association between sex and birth weight of babies was investigated at the University of Maiduguri Teaching Hospital (UMTH). To our knowledge, no such study was performed before in Maiduguri, Borno State, and the entire North-East sub-region of Nigeria. The knowledge obtained could bridge the gap on the paucity of published literature on the relationship between sex and birthweights of babies especially in the North-Eastern part of the country.

\section{Materials and Methods}

The study was carried out at the Department of Paediatrics, and Obstetrics unit of the UMTH, Nigeria. Apart from being the largest health facility in the area, UMTH serves as a referral centre for the six NorthEastern states and neighboring countries of Chad, Cameroon and Niger Republics.

The study protocol was reviewed and authorised by the Medical Research and Ethics Committee of the UMTH. All work was performed according to the international guidelines for human experimentation in clinical research ${ }^{7}$. Informed consent from parents was also obtained. Parents had unlimited liberty to deny consent without any consequences.

The minimum sample size was determined using a statistical formula appropriate for detecting differences between two means when using paired sampling units: the effect size was set at 0.2 , alpha level at 0.05 and power at $95 \%^{8,9}$. However, $50 \%$ of the calculated minimum sample was added to maximize power. Therefore, the sample size for this study was one hundred babies. Babies were eligible for participation in this study if they were delivered at the labour ward of UMTH and met the following study inclusion criteria: (i) singleton birth at term based on fundal height estimate for gestational age or Naegale's rule ${ }^{10}$. (ii) Mothers had no known underlying pregnancy complications, chronic illness and not on drugs other than those used for routine antenatal care. Babies whose mothers smoked cigarettes or drank alcoholic beverages or coffee were excluded from this study. Babies were enrolled in this study using the systematic random sampling method where the first of every four baby was selected at the labour ward. Where the first baby did not fulfil the inclusion criteria above, the immediate next baby that qualified was selected.

On enrolment of babies, information was obtained on delivery outcome which included the sex of the babies. The birth weight of babies in grammes was determined using the bassinet weighing scale which has a sensitivity of 50 grams.

Mean and standard deviation (SD) were calculated for birth weight of babies. The $95 \%$ confidence intervals of the means were calculated as described by Hanley et $\mathrm{al}^{11}$. Likelihood ratio chi-square test of association based on William's criterion was used to investigate the effect of sex on birth weights of the babies ${ }^{12}$. Statistical analysis was performed using statistical package for social science (SPSS) statistical software version 16, Illinois, Chicago USA. Statistical significance was defined as a $p$ value $<0.05$.

\section{Results}

One hundred babies participated in the study. There were 53 (53.0\%) males and 47 (47.0\%) females giving a male to female ratio of 1.1:1. Majority of the babies $82(82.0 \%)$ had normal birth weight (Table 1). Association between birth weight and sex of the babies was significant $\left(x^{2}=9.317, p=0.025\right)$.

Table 1: Association between birth weight and sex of the 100 babies

\begin{tabular}{|c|c|c|c|c|c|}
\hline \multirow[b]{2}{*}{ Sex } & \multicolumn{4}{|c|}{ Birth weight group in grams $[n=(\%)]$} & \multirow[b]{2}{*}{ Total } \\
\hline & $<1500$ & $1500-2499$ & $2500-3900$ & $\geq 4000$ & \\
\hline Male & - & $8(8.0)$ & $41(41.0)$ & $4(4.0)$ & $53(53.0)$ \\
\hline Female & $2(2.0)$ & $4(4.0)$ & $41(41.0)$ & - & $47(47.0)$ \\
\hline Total & $2(2.0)$ & $12(12.0)$ & $82(82.0)$ & $4(4.0)$ & $100(100.0)$ \\
\hline
\end{tabular}

Table 2: Sex and birth weight profile of the study population

\begin{tabular}{|c|c|c|}
\hline & Birth weight $\mathbf{( k g )}$ & \\
\hline Sex & Mean (SD) & $95 \% \mathbf{C l}$ \\
\hline Male & $3.13(0.62)$ & $2.96-3.30$ \\
Female & $2.90(0.55)$ & $2.75-3.07$ \\
\hline
\end{tabular}


Table 2 shows sex and birth weight profile of the subjects. Overall mean (SD) birth weight of the babies was 3.02 (0.59), $95 \mathrm{Cl}(2.91$ - 3.14).

\section{Discussion}

Sex contributed to birth weights of babies in the present study with males having greater birth weights than females. The reason for this finding may possibly be found in the heterogenic nature of male chromosomes unlike the female chromosomes that are homogenous. A past study has documented that the male chromosome may confer some advantages to male over female babies, and this may include males having increased birth weights than females ${ }^{13}$. Some authors have advanced the concept of sexual selection to explain the increase in birth weight of male babies compare to their female counterpart ${ }^{1}$. This was based on the relatively bigger nature of some male organs particularly the brain and testis, believed to be due to accumulation of genes producing multifunctional proteins. One of these genes is SRY, the sex determining gene, which secretes androgens that is responsible for masculinizing male babies $^{6}$. Male babies could have more muscle mass than female babies, thus male babies would have elevated birth weight than female babies. However, other workers have argued against sexual selection; they believed that gene expression in brain and testis that codes for multifunctional proteins in male babies was the result of evolution and not of function ${ }^{14}$.

Other investigators in Scandinavia have reported a contrasting finding to the one made in this study; they reported that parental birth weights correlated with birth weights of their babies ${ }^{3}$. Maternal and paternal birth weights were significantly lower in families who had LBW babies compared with families with no LBW babies. To add, a LBW black mother stand a tripple chance of delivering a LBW baby, compared to double risk seen in their white counterparts ${ }^{3}$. Thus there is evidence of familial trends in determining birth weight of babies possibly due to autosomal genes rather than sex mediated genes. The placenta is critically involved in transporting nutrients and act as a barrier to infection, and fetuses have been observed with confined placental mosaicism ${ }^{15}$. Based on this, other researchers believed that cytogenetic abnormality in the placenta and not the sex of the fetus could be responsible for LBW ${ }^{15}$. How confined placental mosaicism affects fetal growth could presumably be related to alteration in placental functions.

Our inability to assess other possible factors such as information on parental birth weight, placental weight and structure that could contribute to LBW in babies was a drawback to this investigation and remains a limitation of this study. These limitations may have affected the adequate assessment of the association between sex and birth weight outcome of our babies. Future research incorporating these aspects is hereby advocated.

\section{Conclusion}

Sex was found to be a significant determinant of birth weight of babies; with males having higher means birth weight than their female counterparts.

Acknowledgements: We acknowledge the kind help and encouragement we received from the health workers in the labour ward and at the Paediatric department of the UMTH.

Funding: Nil

Conflict of interest: None

Permission from IRB: Yes

\section{References}

1. Graves JAM. Review: Sex Chromosome Evolution and the Expression of Sex-Specific Genes in the Placenta. Placenta 2010;24:27-32.

2. Magnus $P$, Berg K, Bjerkedal $T$, Nancy WE. Parental determinants of birth weight. Clin Genet 1984;26(5):397-405.

3. Johnston LB, Clark AJL, Savage MO. Genetic factors contributing to birth weight. Arch Dis Child Fetal Neonatal Ed 2002;86:2-3.

4. Hattersley AT, Beards F, Ballantyne E, Appleton M. Mutations in the glucokinase gene of the fetus result in reduced birth weight. Nat Genet 1998;19(3):26870.

5. Lahn B, Page DC. Functional coherence of the human Y chromosome. Science 1997;278:675-80.

6. Sinclair AH, Berta P, Palmer MS, Hawkins JR, Griffiths BL, Smith MJ, et al. A gene from the human sex-determining region encodes a protein with homology to a conserved DNA-binding motif. Nature 1990;346:240-4.

7. World Medical Association Declaration of Helsinki. Ethical principles for medical research involving human subjects. World Medical Association, 2000. Available at http://www.wma.net/e/policy/b3.htm. Accessed June 15, 2005.

8. Chellakooty M, Skibsted L, Skouby SO, Andersson $\mathrm{AM}$, Petersen $\mathrm{JH}$, Main $\mathrm{KM}$, et al. Longitudinal Study of Serum Placental GH in 455 Normal Pregnancies: Correlation to Gestational Age, Fetal Gender, and Weight. J Clin Endocrinol Metab 2002; 87(6):2734-39.

9. Browner WS. Estimating sample size and power. In Hulley SB, Cummings SR, Grady D, Hearst N, Newman TB eds. Designing Clinical Research, $2^{\text {nd }}$ ed. Philadelphia: Lippincott Williams \& Wilkins; 2001. P. 65-84. 
10. Basket TF, Nagele F. Nagele's rule: a reappraisal. BJOG 2000;107(11):1433-5.

11. Hanley JA, McNeil BJ. The meaning and use of the area under a receiver operating characteristic (ROC) curve. Radiol 1982;143:29-36.

12. Williams DA. Improved Likelihood Ratio Tests for Complete Contingency Tables. Biometrika 1976;63:33-7.
13. Fisher RA. The evolution of dominance. Biol Rev 1931;6:345-68.

14. Graves JAM. Sex chromosome dynamics and $Y$ chromosome degeneration. Cell 2006;124:901-14.

15. Lestou VS, Kalousek DK. Confined placental mosaicism and intrauterine fetal growth. Arch Dis Child Fetal Neonatal Ed 1998;79:223-6. 